\author{
A. Ziewiec ${ }^{1^{*}}$, A. Zielińska-Lipiec ${ }^{1}$, J. Kowalska ${ }^{1}$, K. Ziewiec ${ }^{2}$ \\ ${ }^{1}$ AGH University of Science and Technology in Krakow, Faculty of Metals Engineering and \\ Industrial Computer Science, al. Mickiewicza 30, 30-059 Krakow, Poland \\ ${ }^{2}$ Pedagogical University of Cracow, Faculty of Mathematics, Physics and Technical Science, \\ Institute of Technology, ul. Podchorażych 2, 30-084 Kraków, Poland \\ *aziewiec@agh.edu.pl
}

\title{
MICROSTRUCTURE CHARACTERIZATION OF WELDS IN X5CrNiCuNb16-4 STEEL IN OVERAGED CONDITION
}

\begin{abstract}
The paper presents the results of the investigation of microstructure of the welded $\mathrm{X} 5 \mathrm{CrNiCuNb} 16-4(17-4 \mathrm{PH})$ steel after solution treatment and aging at $620^{\circ} \mathrm{C}$ for different periods. The microstructure and the phase composition of the steel was investigated using light microscopy (LM), scanning electron microscopy (SEM), energy dispersive spectrometry (EDS), transmission electron microscopy (TEM) and the X-ray diffraction (XRD). Hardness was measured for samples aged at different times. Density distributions of $\mathrm{Cu}$ precipitates were established. The investigation has shown that the microstructure of the X $5 \mathrm{CrNiCuNb} 16-4$ steel welds after aging at $620^{\circ} \mathrm{C}$ consists of tempered martensite, fine $\mathrm{Cu}$ precipitates and austenite. It was observed that the size of the $\mathrm{Cu}$ precipitates increases with increasing the aging time, what affects the decrease of hardness. Simultaneously, the quantity of reversed austenite increases with increase of aging time. It was revealed that enrichment of the austenite in $\mathrm{Ni}, \mathrm{Cu}$ and $\mathrm{C}$ affects the increase of $\mathrm{M}_{\mathrm{s}}$, but this factor does not determine the stability of austenite.
\end{abstract}

Keywords: welds, 17-4PH steel; reversed austenite; martensitic PH stainless steels; aging

\section{INTRODUCTION}

Precipitation hardened stainless steels, due to their combination of mechanical properties and corrosion resistance, are commonly used as a construction material for power engineering and chemical and aviation industry. One of the most common steels belonging to this group is 17-4PH (XCrNiCu16-4-3). This steel contains ca. 3 wt. \% $\mathrm{Cu}$ and is hardened by $\mathrm{Cu}-\mathrm{fcc}$ precipitates in the martensitic matrix $[1,2,3]$.

After solution treatment at $1038^{\circ} \mathrm{C} \pm 14^{\circ} \mathrm{C}$ (Condition A) the steel is tempered at $482^{\circ} \mathrm{C}$ for $1 \mathrm{~h}$ (Condition $\mathrm{H} 900$ ), at $496^{\circ} \mathrm{C}$ for $4 \mathrm{~h}$ (Condition $\left.\mathrm{H} 925\right), 551{ }^{\circ} \mathrm{C}$ for $4 \mathrm{~h}$ (Condition $\mathrm{H} 1025$ ), $580^{\circ} \mathrm{C}$ for $4 \mathrm{~h}$ (Condition $\mathrm{H} 1075$ ), $593^{\circ} \mathrm{C}$ at $4 \mathrm{~h}$ (Condition $\mathrm{H} 1100$ ) or $621^{\circ} \mathrm{C}$ for $4 \mathrm{~h}$ (Condition 
H1150). After solution treatment the 17-4 PH steel has martensitic microstructure but the hardness is moderately high. Aging that follows this treatment leads to precipitation of phases enriched in $\mathrm{Cu}$ and consequently to strengthening and hardening [4-9]. It is considered that the excellent mechanical properties and plasticity of stainless steels derive from the reversed austenite. This austenite is mechanically unstable and thermally stable [10, 11]. However, thermal stability of reversed austenite is still not understood. Many hypotheses propose an explanation for this phenomenon. Rao et al. $[12,13]$ suggested that the austenite stability can be attributed to compression stresses causing $90 \%$ of martensite to be created during cooling. Sha et al. [11] suggested that concentration of $\mathrm{Ni}$ in austenite may decide about its stability.

Reversed austenite can be effectively used in many types of steel, such as maraging steels, TRIP steels, austenitic TWIP $[14,15,16]$. These steels are often joined by GTAW welding. The steel parts are often repaired by welding and it is a common technique of reducing costs. However, rapid solidification during welding modifies the structure of the weld and heat affected zone [17]. In order to obtain weld properties similar to those of the base material, the post-weld heat treatment (PWHT) is inevitable. The use of post-weld heat treatment also increase hardness of the weld, HAZ and the base material. Such effect is in the opposite to the high-strength structural steels [18] and advanced steels for power plants [19]. Application of solution treatment before aging results in decreasing the quantity of delta ferrite and improves its resistance [20,21].

The strength and toughness of the weld decrease with increasing aging temperature above $540^{\circ} \mathrm{C}$ as a result of the growth of precipitates of $\mathrm{Cu}[5,20]$. Due to a good combination of strength and plastic properties as well as uniform corrosion in chloride acid environment [17, $22]$ the steel is used in the overaged condition. The 17-4PH steel in overaged state is also used for large size construction parts that are to be welded. In such a case the overaged condition guarantees optimum weldability.

There is a need for detailed study of microstructure formed during aging of 17-4 PH steel welds, in particular the research of the welded joints in terms of reversed austenite. Most of the previous studies on steel 17-4PH were focused on the effects of aging on the microstructure and mechanical properties of the base material [23-28]. Only a few reports were related to the weld of the material [5, 17, 29-31]. Therefore, the present work is focused on detailed characterization of microstructure of the welded joints in overaged condition, using XRD, LM, SEM, TEM. Volume fraction of the reversed austenite was calculated and measurements were performed of $\mathrm{Cu}$ particle size after aging at the temperature of $620^{\circ} \mathrm{C}$.

\section{EXPERIMENTAL}

The material used for the test was $\mathrm{X} 5 \mathrm{CrNiCuNb} 16-4$ steel $(17-4 \mathrm{PH})$ of the chemical composition given in Table 1.

Table 1. Chemical composition of 17-4PH base metal

\begin{tabular}{|c|c|c|c|c|c|c|c|}
\hline Element & $\mathrm{C}$ & $\mathrm{Cr}$ & $\mathrm{Ni}$ & $\mathrm{Cu}$ & $\mathrm{Si}$ & $\mathrm{Mn}$ & $\mathrm{Nb}$ \\
\hline $\begin{array}{c}\text { Concentration, } \\
\text { wt \% }\end{array}$ & 0.061 & 16.5 & 4.0 & 3.4 & 0.58 & 0.6 & 0.35 \\
\hline
\end{tabular}


The base metal was received by cutting out the slice of $10 \mathrm{~mm}$ thickness from the 110 $\mathrm{mm}$ diameter rod. Then the slice was cut in half along the diameter and the both halves of the $10 \mathrm{~mm}$ thick slices were autogenously welded using the GTAW method. The welding parameters were following: current $-100 \mathrm{~A}$, arc voltage $-12 \mathrm{~V}$ and the welding speed -1.5 $\mathrm{mm} / \mathrm{s}$. The butt welded joint was cut perpendicularly to the welding direction into the $10 \mathrm{~mm}$ thick samples. Then the samples were solution treated at $1050^{\circ} \mathrm{C}$ for $1 \mathrm{~h}$ and isothermally aged at $620^{\circ} \mathrm{C}$ under argon atmosphere. Duration of the aging was from 0.5 to $10 \mathrm{~h}$.

In order to observe the changes of properties due to the increase of aging time, the hardness of the samples was measured using HPO-250 Vickers durometer. Hardness measurements were performed on weld cross-section of a welded joint with a load of $10 \mathrm{kG}$ $(98.07 \mathrm{~N})$. Microstructure of the steel welds was investigated made using LM light microscope Leica DMLM. The samples were digested in Villela's etchant. Thin foils for TEM investigation were prepared by slicing, grinding and finally iron milling. TEM microstructural analysis was carried out using performed on a transmission electron microscope JEOL 200CX. In order to determine the size distributions of $\mathrm{Cu}$ precipitates and the average particle size after aging at temperature $620^{\circ} \mathrm{C}$ for $1 \mathrm{~h}$ and $4 \mathrm{~h}$. ImageJ freeware program was used to analyze data. In each case, approximately 500 particles were analyzed (approx. 15 fields) on a series of TEM micrographs acquired in TEM bright-field mode at magnification 50 000x. Digital TEM images were calibrated according to the magnification scale and the distance of $1 \mathrm{~nm}$ corresponded to a 0.704 of pixel. The particles were manually marked and their areas were measured. Afterwards, the equivalent diameter $D_{p}$ was calculated for every precipitate, and it was treated as the particle size. The particle diameter distributions were determined. Then the average particle diameters and standard deviations were calculated.

XRD studies were carried out in order to measure the volume fraction of austenite in samples after aging at $620^{\circ} \mathrm{C}$. The XRD were performed on a Siemens D500 Diffractometer, using the monochromatic radiation of a copper X-ray tube $\left(\lambda_{\mathrm{Cu}} \mathrm{K}_{\alpha}=1.54 \AA\right)$. Diffraction pattern was determined with the use of Bragg-Brentano method, using step-counting $(\Delta 2 \theta=$ $0.02^{\circ}$, time per step $\tau=5 \mathrm{~s}$ ) in the angle range $2 \theta$ from $35^{\circ}$ to $90^{\circ}$.

Afterwards, the sections of the welds after aging at $620^{\circ} \mathrm{C}$ for $4 \mathrm{~h}$ were examined using scanning electron microscope (SEM) equipped with an energy dispersive spectrometer (EDS) JEOL 6610. EDS analysis was performed on several randomly selected sites. Then average concentration of elements for the core and the cells boundaries was determined. The analysis of EDS for larger areas of the weld was also performed.

\section{RESULTS}

Figure 1 shows the results of hardness measurements in the weld, depending on the aging time, for aging temperature of $620^{\circ} \mathrm{C}$. It was observed that starting from aging time as large as $0.5 \mathrm{~h}$, hardness decreases with increasing aging time. This means that the overaging condition occurs in the welds at $620^{\circ} \mathrm{C}$ for the aging periods starting from $0.5 \mathrm{~h}$. 


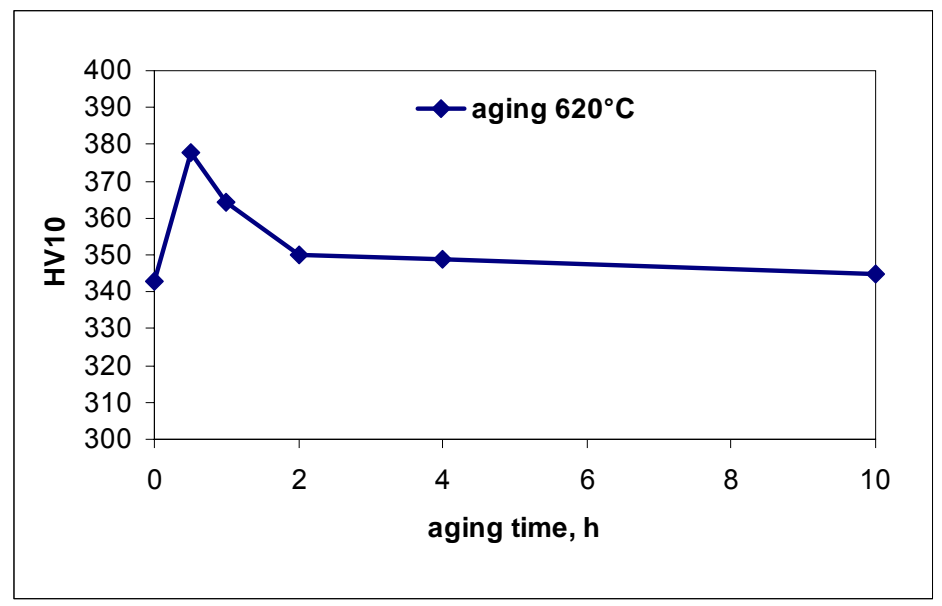

Fig 1. Hardness of the weld as a function of time for aging time at temperature $620^{\circ} \mathrm{C}$.

a

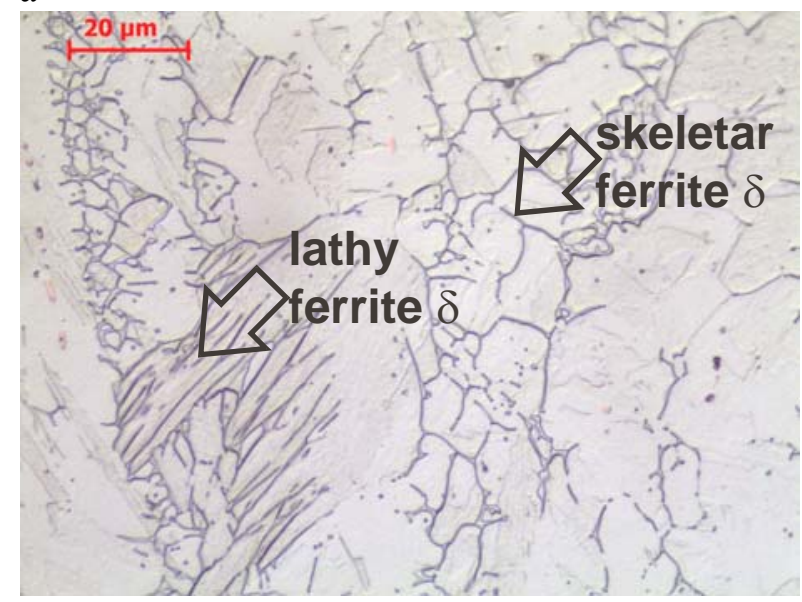

$\mathrm{c}$

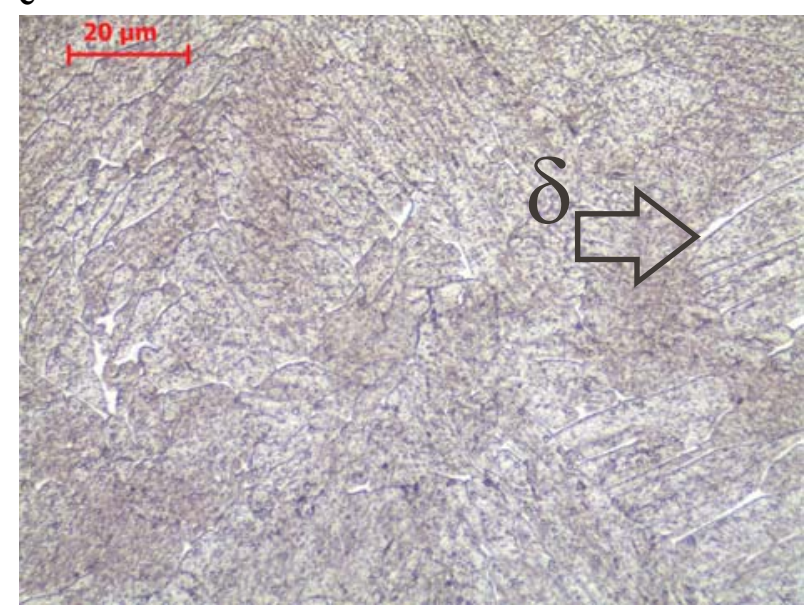

b

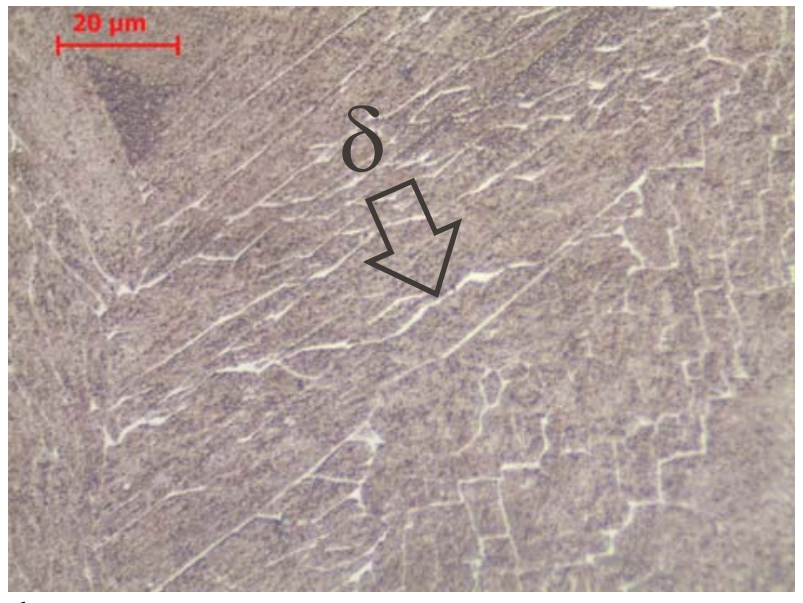

d

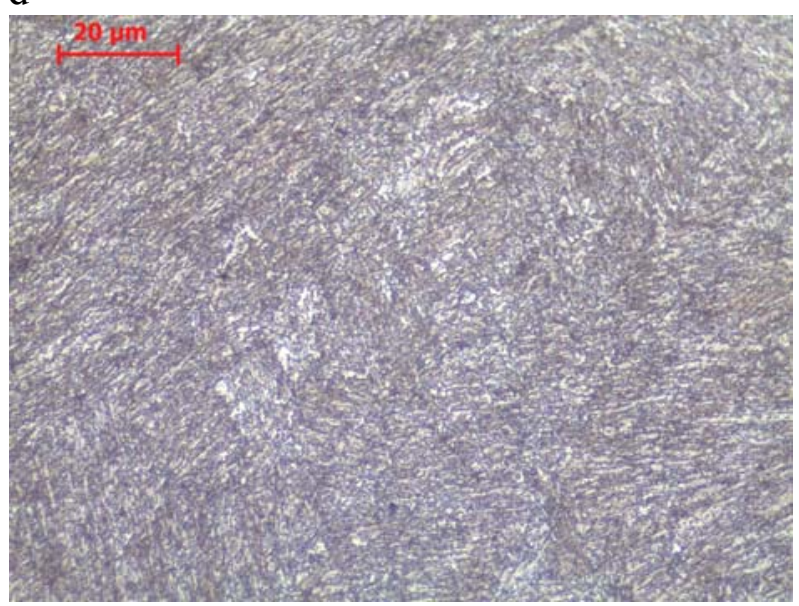

Fig. 2. LM images of the weld microstructure: (a) after welding, (b) aged at $620^{\circ} \mathrm{C} / 0,5 \mathrm{~h}$, (c) aged at $620^{\circ} \mathrm{C} / 1 \mathrm{~h}$, (d) aged at $620^{\circ} \mathrm{C} / 4 \mathrm{~h}$

In order to clarify the transformations occurring during aging at the temperature of $620^{\circ} \mathrm{C}$ microstructural studies were conducted. LM studies indicate that the microstructure of the weld is martensitic, containing skeletar $\delta$ ferrite and lathy $\delta$ ferrite (Fig. 2). After aging at 
$620^{\circ} \mathrm{C}$, tempered martensite microstructure with carbide precipitates distributed along the strips of martensite and ferrite $\delta$ (Fig. 3) is observed. TEM studies have shown that these precipitates are $\mathrm{M}_{23} \mathrm{C}_{6}$ type carbides. In addition, in the microstructure there is austenite distributed within martensite laths and austenite within a martensite matrix. TEM microstructure of reversed austenite after aging at $620^{\circ} \mathrm{C}$ for $4 \mathrm{~h}$ shown in Figure 4 . The fine austenite plates are darker areas with locally increased density of dislocations. There is Kurdiumow-Sachs (KS) relationship between the martensitic matrix and austenite.

a

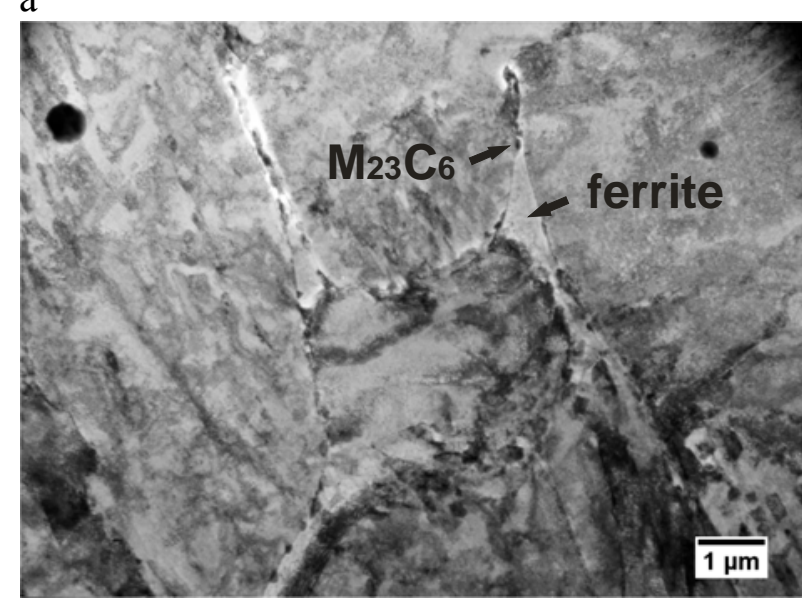

C

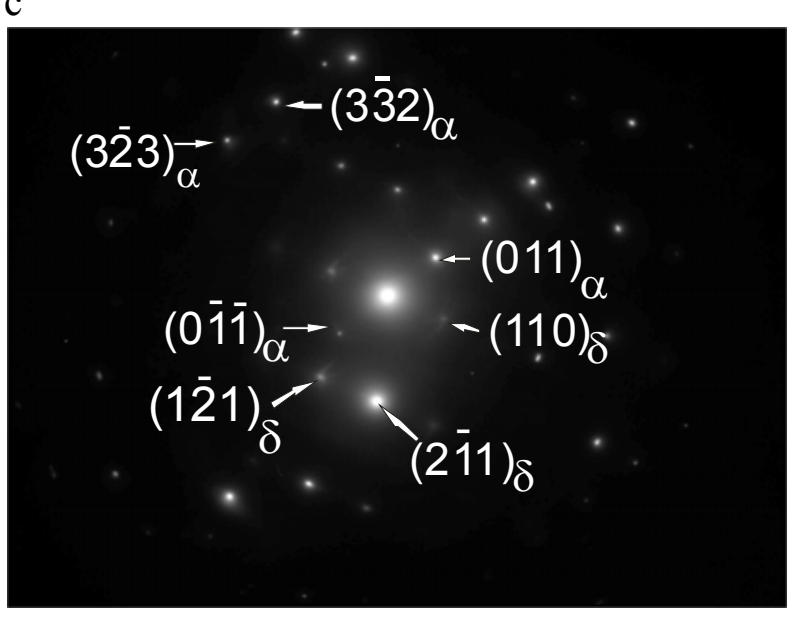

b

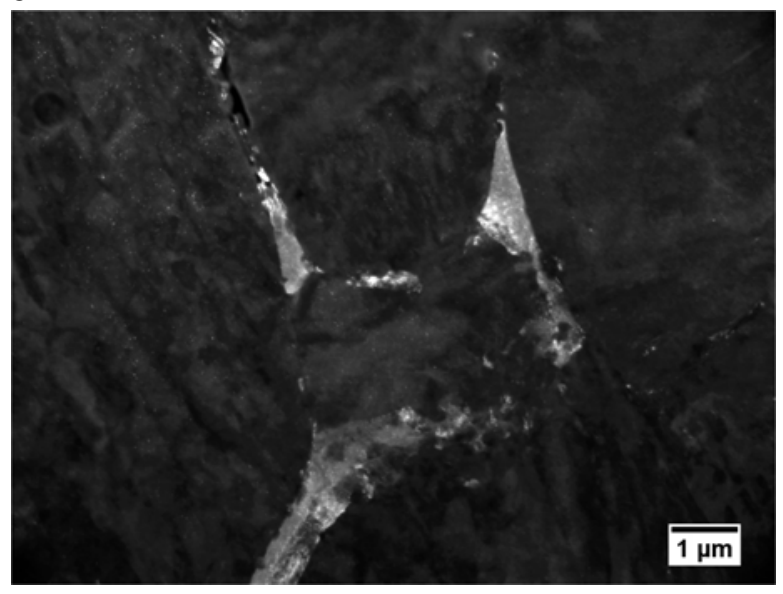

Fig. 3. Weld microstructure of 17-4PH steel after aging at $620^{\circ} \mathrm{C}$ for $1 \mathrm{~h}$, a) bright-field, b) dark-field c) from $[\overline{5} 33]_{\text {all }}[\overline{11} 3]_{\delta}$ diffraction axis

There are small fcc $\mathrm{Cu}$ precipitates (Fig. 5a) in the microstructure after aging at $620^{\circ} \mathrm{C}$ for 1 hour. The size of $\mathrm{Cu}$ precipitates increases with the increase aging time (Fig. 5b). Size distributions of the precipitates after aging at temperature $620^{\circ} \mathrm{C}$ for $1 \mathrm{~h}$ and $4 \mathrm{~h}$ are shown in Fig 6. The results of measurements are shown in Table 2. The average size of $\mathrm{Cu}$ precipitates after aging for $1 \mathrm{~h}$ was $16 \mathrm{~nm}$. The increase of aging time to $4 \mathrm{~h}$ resulted in the increase of the size to $21 \mathrm{~nm}$. 


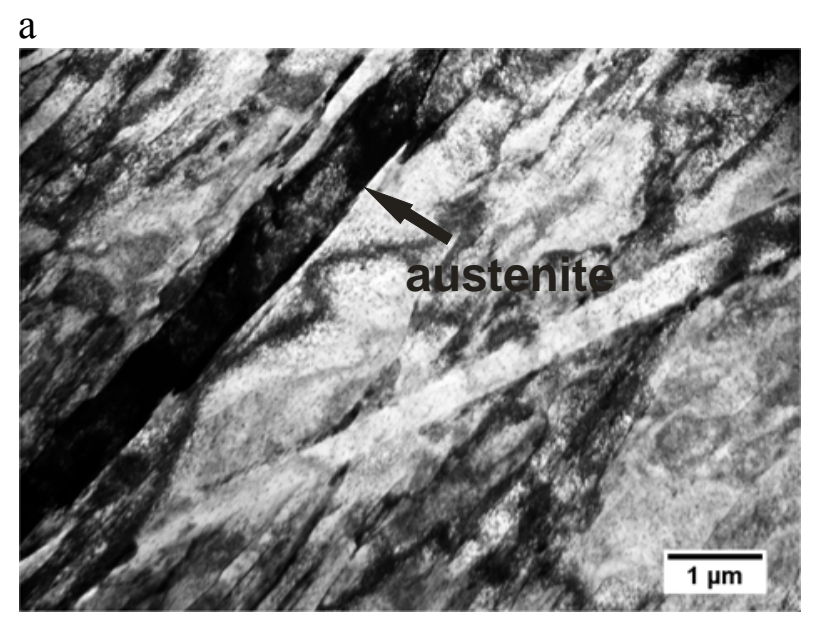

b

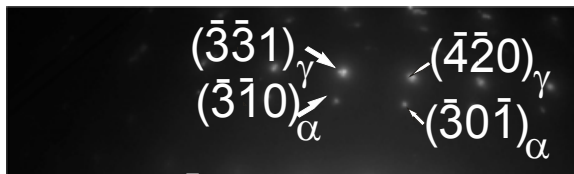

Fig. 4. a) The morfology of the reversed austenite in welds of $17-4 \mathrm{PH}$ steel after aging at $620^{\circ} \mathrm{C}$ for $4 \mathrm{~h} \mathrm{~b}$ ) from $[\overline{1} 23]_{\gamma}\left\|[\overline{13} 3]_{\alpha}\right\|[001]_{\alpha}$ diffraction axis

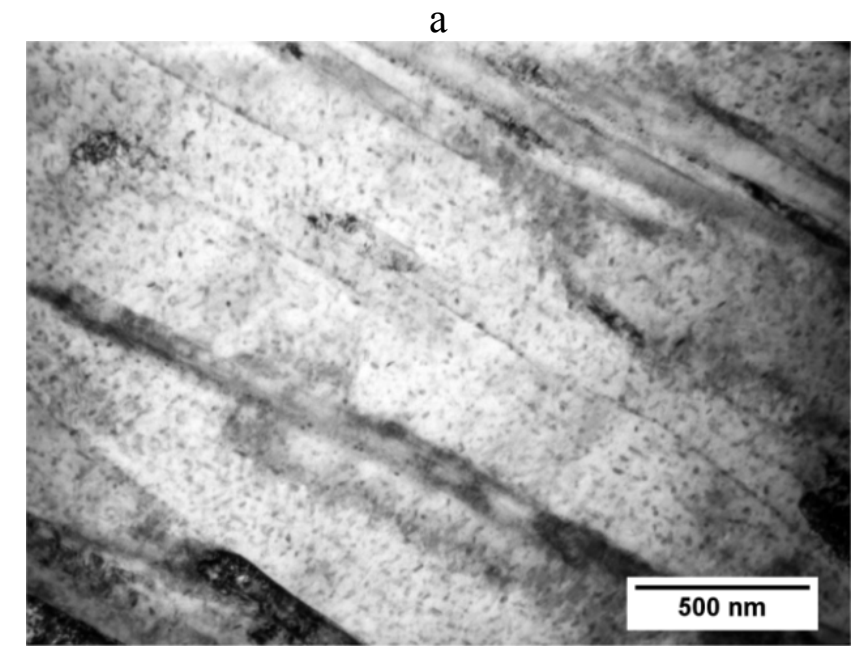

b

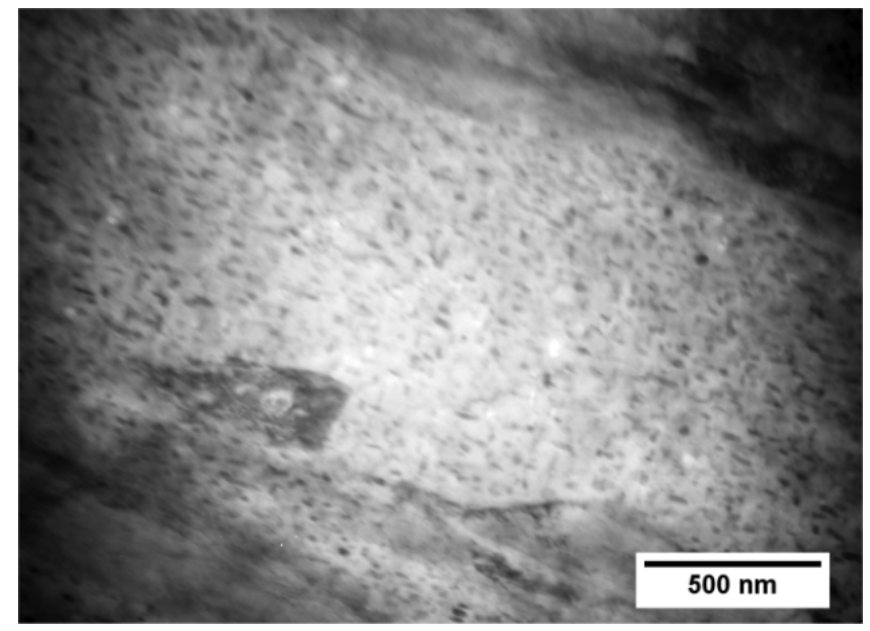

Fig. 5. TEM images of fcc-copper in weld 17-4PH steel after aging at temperature $620^{\circ} \mathrm{C}$ for a) $1 \mathrm{~h}$, b) $4 \mathrm{~h}$ 

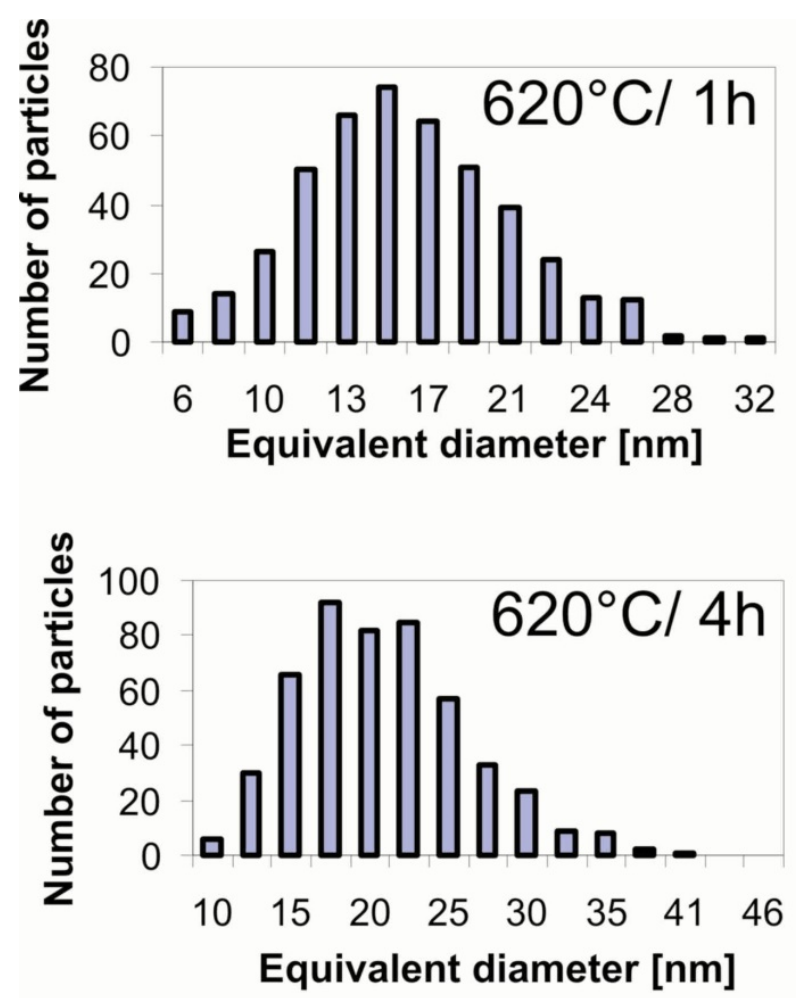

Fig. 6. Size distributions of fcc-Cu precipitates after aging at temperature $620^{\circ} \mathrm{C}$ for $1 \mathrm{~h}$ and $4 \mathrm{~h}$

Table 2. Parameters of the empirical distribution of Cu precipitates size, $\mathrm{nm}$

\begin{tabular}{|l|c|c|}
\hline $\begin{array}{l}\text { The parameters of the } \\
\text { empirical distribution, } \mathrm{nm}\end{array}$ & $620^{\circ} \mathrm{C} / 1 \mathrm{~h}$ & $620^{\circ} \mathrm{C} / 4 \mathrm{~h}$ \\
\hline $\begin{array}{l}\text { Weighted average (number) } \\
(\mathrm{Dp})\end{array}$ & 16.1 & 20.9 \\
\hline Variance (series) & 21.2 & 30.7 \\
\hline $\begin{array}{l}\text { The average deviation } \\
\text { (number) }\end{array}$ & 2.6 & 3.5 \\
\hline arithmetic average & 16.1 & 20.9 \\
\hline Variance & 21.2 & 31.8 \\
\hline The average deviation & 2.7 & 3.6 \\
\hline
\end{tabular}

The XRD results of the weld after welding and aging are shown in Fig. 7. The diffraction confirms the presence of the martensitic/ferritic microstructure. There are also small peaks from austenite. The calculated amount of austenite after welding is similar to the amount after welding and solution treatment, which is ca. $2.8 \%$ by volume (Table 3 ). When comparing the condition after welding to the state after welding and aging for $1 \mathrm{~h}$, the peak intensity of the austenite is greater after aging for $1 \mathrm{~h}$. The peak intensity from austenite increases with increase of the aging time. Quantitative analysis showed that the volume fraction of austenite for the aging time of $1 \mathrm{~h}$ is $5.9 \%$, while for $4 \mathrm{~h}$ it increased to $7.3 \%$. 


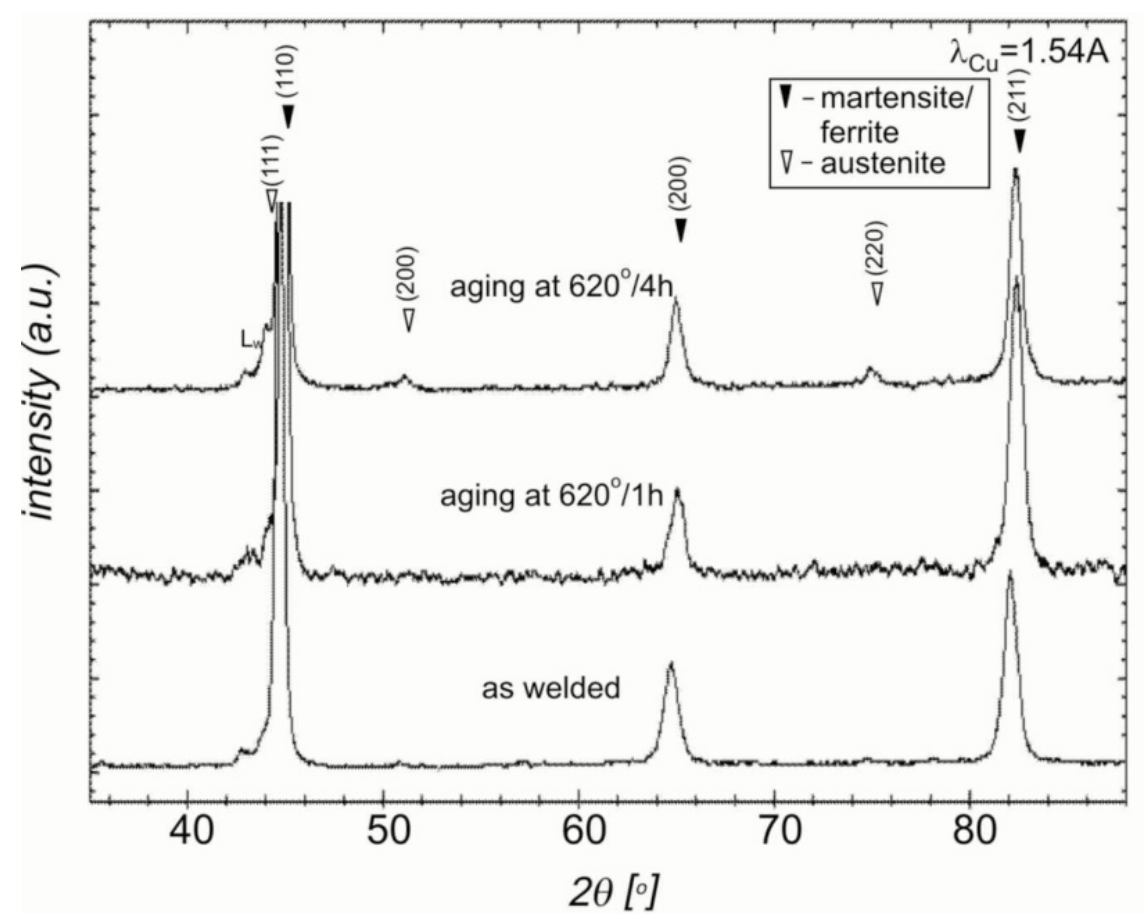

Fig. 7. XRD spectra of the welds in as-welded condition and after aging at $620^{\circ} \mathrm{C}$ for $1 \mathrm{~h}$ and $4 \mathrm{~h}$

Table 3. Volume fraction of austenite for various conditions of heat treatment, and a lattice parameter of austenite determined by XRD measurements

\begin{tabular}{|c|c|c|c|}
\hline Heat treatment & $\mathrm{V}_{\gamma}[\%]$ & $\delta \mathrm{V}_{\gamma}[\%]$ & $\mathrm{a}_{\mathrm{o \gamma}}[\AA]$ \\
\hline As-welded & 2.8 & 0.1 & 3,60778 \\
\hline $620^{\circ} \mathrm{C} / 1 \mathrm{~h}$ & 5.9 & 0.1 & 3,60660 \\
\hline $620^{\circ} \mathrm{C} / 4 \mathrm{~h}$ & 7.3 & 0.1 & 3,59196 \\
\hline
\end{tabular}

EDS analysis showed that the average chemical composition of the weld is $17.1 \% \mathrm{Cr}$, $4.8 \% \mathrm{Ni}$ and $\mathrm{Cu} 2.9 \%$ (Table 4). EDS line analysis indicated that the elemental distribution of $\mathrm{Ni}, \mathrm{Cr}$ and $\mathrm{Fe}$, and in a small extent of $\mathrm{Cu}$ differentiates across the grains. The boundaries of cells are enriched in $\mathrm{Ni}$ and $\mathrm{Fe}, \mathrm{Cu}$, and the cell cores are richer in $\mathrm{Cr}$. The average chemical composition of the cell boundary is ca. $16.7 \% \mathrm{Cr}, 5.6 \% \mathrm{Ni}$ and $3.1 \% \mathrm{Cu}$, and the cell core contains $17.2 \% \mathrm{Cr}, 4.4 \% \mathrm{Ni}$ and $2.7 \% \mathrm{Cu}$ (Fig. $8 \mathrm{a}, \mathrm{b}$ ). This indicates that the cell boundaries are slightly enriched in $\mathrm{Ni}$ and $\mathrm{Cu}$ in comparison with the average composition of the weld. The exemplary EDS spectra at the cell boundary (A) and the cell core (B) are shown in Fig. $8 \mathrm{c}$. 
a

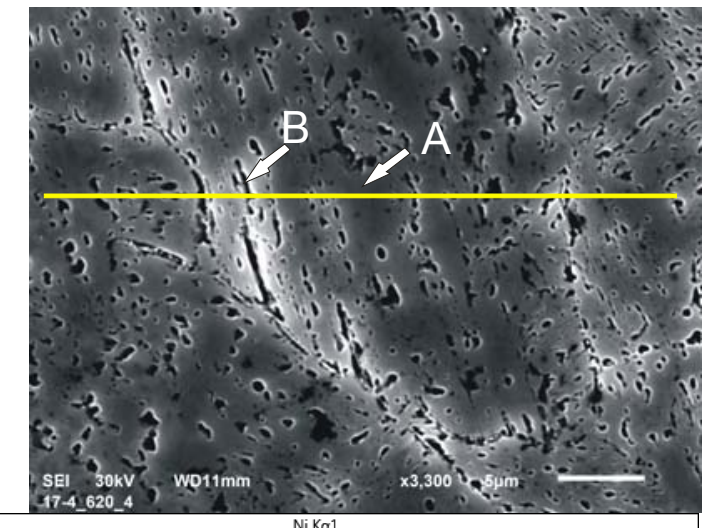

b
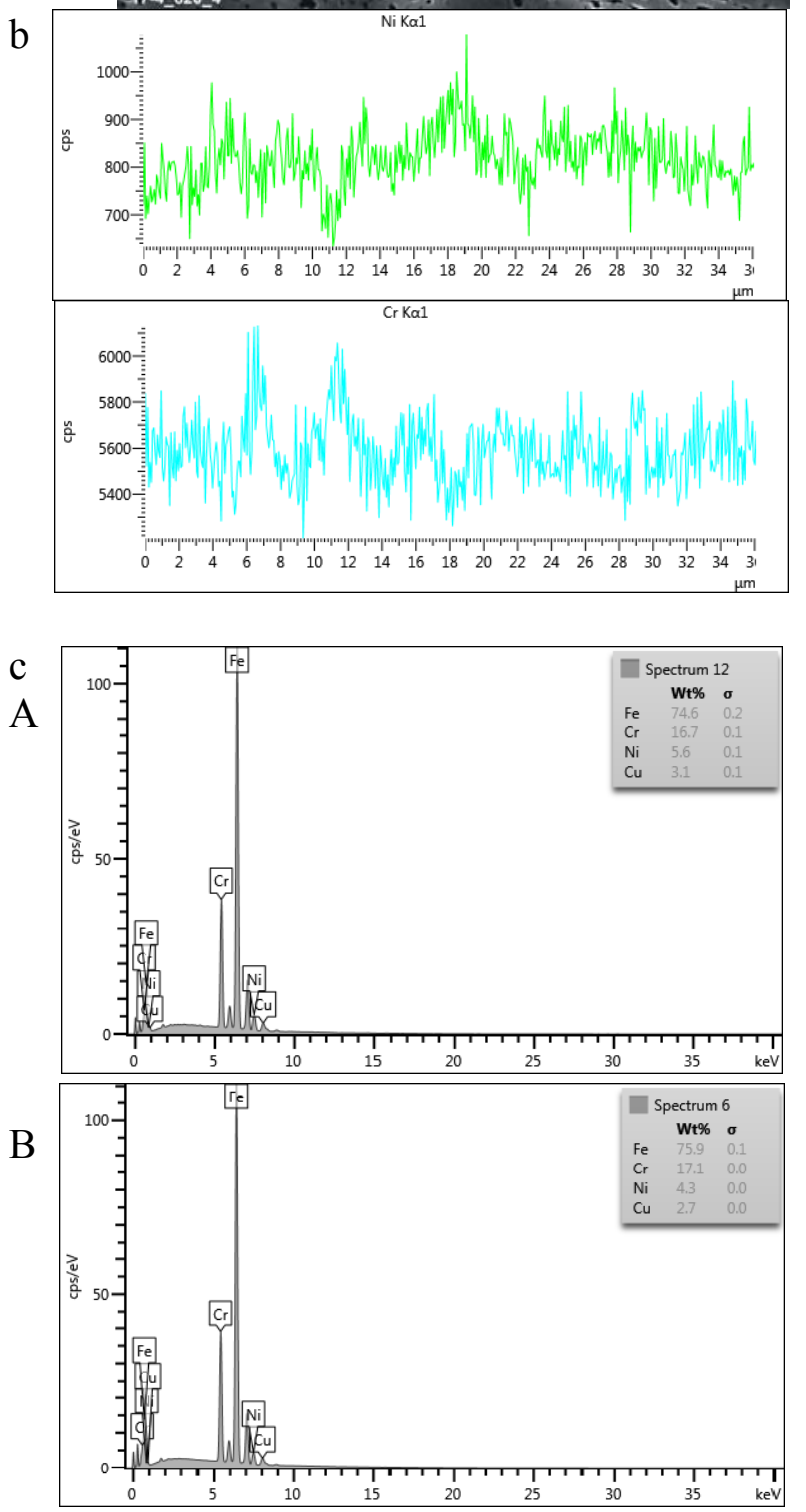

Fig. 8. a) SEM image of the microstructure of the weld after aging at $620^{\circ} \mathrm{C}$ for $4 \mathrm{~h}$, b) EDS line scan of $\mathrm{Ni}, \mathrm{Cr}$, c) EDS spectra from the points marked in Figure 8a (A-boundary of the cell, B-core of the cell ) 
Table 4. The mean concentrations of $\mathrm{Cr}$, Ni, Cu, the weld samples aged at $620^{\circ} \mathrm{C}$ for 4 hours, determined by multiple point EDS analysis in SEM, wt. \%

\begin{tabular}{|c|c|c|c|}
\hline $\begin{array}{c}\text { Element, } \\
\text { wt.\% }\end{array}$ & Weld metal & Boundary of a cell & Core of a cell \\
\hline $\mathrm{Cr}$ & $17.1 \pm 0.1$ & $16.9 \pm 0.1$ & $17.2 \pm 0.1$ \\
\hline $\mathrm{Ni}$ & $4.8 \pm 0.1$ & $5.6 \pm 0.1$ & $4.4 \pm 0.1$ \\
\hline $\mathrm{Cu}$ & $2.9 \pm 0.1$ & $3.1 \pm 0.1$ & $2.7 \pm 0.1$ \\
\hline
\end{tabular}

\section{DISCUSSION}

The presence of $\delta$ ferrite in the weld can be explained on the basis of primary ferrite mode. Calculated $\mathrm{R}_{\mathrm{Cr}} / \mathrm{R}_{\mathrm{Ni}}$ for the test steel $17-4 \mathrm{PH}$ is 2.86 . Because of the fact that $\mathrm{R}_{\mathrm{Cr}} / \mathrm{R}_{\mathrm{Ni}}$ is above $1.48,17-4 \mathrm{PH}$ steels solidify with the primary ferrite mode. The transformation of $\delta$ ferrite to austenite begins at around $1300^{\circ} \mathrm{C}$ and ends near $1200^{\circ} \mathrm{C}$ in the case of equilibrium conditions [1].

In the course of equilibrium cooling most of $\delta$ ferrite is transformed into austenite, and then into martensite. However, high cooling rates occurring after welding partially limit the transformation of $\delta$ ferrite transformation into $\gamma$ austenite. As a result, the weld structure is composed of martensite, $\delta$ ferrite and small amount of austenite. After the ending of the weld, a certain stress state still remains. Furthermore, non-equilibrium solidification conditions associated with rapid cooling of the material can lead to an uneven distribution of elements across the width of the crystallites. Research of Song [6] on another martensitic steel have shown that these areas have uneven distribution of $\mathrm{C}$. Actual levels of $\mathrm{C}$ content for the studied steel was determined by XRD measurement of the lattice parameter (Table 3). The measured lattice parameter in the austenite welds aged at $620^{\circ} \mathrm{C}$ for $4 \mathrm{~h}$ was $\mathrm{a}_{\mathrm{or}}=3,59196 \AA$. This value was assumed for calculation of the $C$ concentration using equation (1) [32, 33].

$$
\mathrm{a}_{\mathrm{o \gamma}}=3,572+0,033 \cdot(\text { wt. } \% \mathrm{C})
$$

According to this equation the calculated content of $\mathrm{C}$ is $0.605 \mathrm{wt} . \%$. The present studies have shown that the cell boundaries are also enriched in $\mathrm{Ni}$ and $\mathrm{Cu}$. When the samples are aged, local areas of martensite are richer in $\mathrm{Ni}$ and $\mathrm{Cu}$ as well as in $\mathrm{C}$ may be at temperatures slightly higher than the $\mathrm{A}_{\mathrm{cl}}$. Therefore, during aging, some fraction of martensite enriched in $\mathrm{Ni}, \mathrm{Cu}$ and $\mathrm{C}$ is transformed into reversed austenite.

The enrichment of the austenite $\mathrm{Ni}, \mathrm{Cu}$ and $\mathrm{C}$ leads to a reduction in temperature of the $\mathrm{M}_{\mathrm{s}}$ of these areas relative to the average composition of the weld. $\mathrm{M}_{\mathrm{s}}$ temperature was calculated by the formula [34]:

$$
\mathrm{M}_{\mathrm{s}}[\mathrm{K}]=575-330 \mathrm{C}+2 \mathrm{Al}+7 \mathrm{Co}-14 \mathrm{Cr}-13 \mathrm{Cu}-23 \mathrm{Mn}-5 \mathrm{Mo}-4 \mathrm{Ni}-7 \mathrm{Si}+3 \mathrm{Ti}+4 \mathrm{~V}
$$

$\mathrm{M}_{\mathrm{s}}$ temperature calculated for the cell boundaries is $-68^{\circ} \mathrm{C}$, while $\mathrm{M}_{\mathrm{s}}$ value for weld is $57^{\circ} \mathrm{C}$. For the cell core the $\mathrm{M}_{\mathrm{s}}$ temperature is $-51^{\circ} \mathrm{C}$. During cooling after aging part of austenite transforms into fresh martensite again. Additionally the martensitic transformation induces compressive stresses which inhibit transformation of austenite to martensite. The areas enriched in $\mathrm{Ni}, \mathrm{Cu}$ and $\mathrm{C}$ can reach such concentration of these elements that they are not transformed into martensite and these areas remain in the microstructure after aging in the form of reversed austenite. This indicates that enrichment of the austenite in the $\mathrm{Ni}, \mathrm{Cu}$ and $\mathrm{C}$ can be a factor affecting the thermal stability of the austenite. However, this factor is not the only one. TEM observations revealed that the reversed austenite locally has a very high 
density of dislocations. This may mean that the austenite has been deformed due to the phase transformation during the formation of fresh martensite. Therefore, it is possible that the substructure observed in austenite may also affect its stability. Another factor is the martensite transformation that causes compressive stress supported by the welding process, which inhibit the transformation of austenite to martensite.

\section{CONCLUSIONS}

1. The present study has shown that the microstructure of $17-4 \mathrm{PH}$ steel after welding includes martensite, $\delta$ ferrite and small amounts of austenite. After aging at $620^{\circ} \mathrm{C}$, the microstructure is composed of tempered martensite, fine dispersive $\mathrm{Cu}$ precipitates and the reversed austenite. Austenite has acicular or plate-like morphology and locally has a very high density of dislocations. This suggests that the austenite has been deformed due to the phase transformation during the formation of fresh martensite.

2. The prolonged aging leads to decrease of hardness as a result of the coagulation of fcc-Cu precipitates and increase of the amount of reversed austenite.

3. The enrichment of the austenite in $\mathrm{Ni}, \mathrm{Cu}$ and $\mathrm{C}$ may result in the increase the $\mathrm{M}_{\mathrm{s}}$ temperature, but this is not the only and determining factor influencing the stability of the austenite. The high dislocation density in certain areas of reversed austenite suggests that the stability of the austenite can have both chemical and substructural base.

\section{AKNOWLEDGMENTS}

The research was carried out within the statutory research project no 16.16.110.663.

\section{REFERENCES}

1. Bilmes P. D., Solari M., Llorente C.L.: Characteristics and effects of austenite resulting from tempering of $13 \mathrm{Cr}-\mathrm{NiMo}$ martensitic steel weld metals. Materials Characterization 46 (2001) 285-296.

2. Antony K.C.:_Aging Reactions in Precipitation Hardenable Stainless Steel. Metall. J. 15 (1963) $1595-1605$.

3. Murayama M., Katayama Y., Hono K.: Microstructural evolution in a 17-4 PH stainless steel after aging at $400{ }^{\circ} \mathrm{C}$. Metallurgical and Material Transations A 30/2 (1999) 345-353.

4. http://www.aksteel.com/pdf/markets_products/stainless/precipitation/17-4_ph_data_sheet.pdf, 11.06.2015.

5. Ziewiec A., Zielińska-Lipiec A., Tasak E.: Microstructure of welded joints of X5CrNiCuNb16-4 (17-4 PH) martensitic stainless steel after heat treatment. Archives of Metallurgy and Materials 59/3 (2014) 965-970.

6. Song Y., Li X., Rong L. and Li Y.: Anomalous phase transformation from martensite to austenite in $\mathrm{Fe}-13 \% \mathrm{Cr}-4 \% \mathrm{Ni}-\mathrm{Mo}$ martensitic stainless steel. Journal of Materials Science and Technology 26/9 (2010) 823-826. 
7. Schönbauer B. M., Yanase K., Endo M.: The influence of various types of small defects on the fatigue limit of precipitation-hardened 17-4PH stainless steel. Theoretical and Applied Fracture Mechanics 87 (2017) 35-49.

8. Tavares S. S. M., Machado C. L. C., Oliveira I. G., Martins, T. R. B. Masoumi M.: Damage associated with the interaction between hydrogen and microstructure in a high sulfur $17-4 \mathrm{PH}$ steel for studs. Engineering Failure Analysis, 82 (2017) 642-647.

9. Daoxin D. L., Xiaohua L., Chengsong Z., Ao L. N.: Surface nanocrystallization of 17-4 precipitation-hardening stainless steel subjected to ultrasonic surface rolling process. Materials Science and Engineering A 726 (2018) 69-81.

10. Bhadeshia H. K. D. H. and Edmonds D. V.: The Distribution of retained austenite in martensite and the influence of inter-lath crystallography, Proc. $3^{\text {rd }}$ Int. Conf. On Martensitic Transformation, Cambridge, Massachusetts, U.S.A., 1979, 28-33.

11. Sha W., Cerezo and Smith G. D. W.: Phase chemistry and precipitation reactions in maraging steels: Part I. Introduction and study of Co-containing C-300 steel, Metallurgical and Material Transations A 24 (1993) 1221-1232.

12. Leem D.S., Lee Y.D., Jun J.H. and Choi C. S.: Amount of retained austenite at room temperature after reverse transformation of martensite to austenite in an $\mathrm{Fe}-13 \% \mathrm{Cr}-7 \% \mathrm{Ni}-3 \% \mathrm{Si}$ martensitic stainless steel. Scripta Materialia 45 (2001) 772.

13. Rao V.N. and Thomas G.: Proc. $3^{\text {rd }}$ Int. Conf. On Martensitic Transformation, Cambridge, Massachusetts, U.S.A., 1979, 12-13.

14. Kowalska J., Ratuszek W., Witkowska M., Zielińska-Lipiec A., Development of microstructure and texture in Fe-26Mn-3Si-3Al alloy during cold-rolling and annealing. Journal of Alloys and Compounds 615 (2014) 583-586.

15. Kowalska J., Ratuszek W., Chruściel K.: Crystallographic relations between deformation and annealing texture in austenitic steels. Archives of Metallurgy and Materials 53/1 (2008) 131-137.

16. Witkowska M., Zielińska-Lipiec A., Kowalska J., W. Ratuszek, Microstructural Changes in a High-Manganese Austenitic Fe-Mn-Al-C Steel, Archives of Metallurgy and Materials 59 (2014) 971-975.

17. Das C. R. et al: Weldability of $17-4 \mathrm{PH}$ stainless steel in overaged heat treated condition. Science and Technology of Welding and Joining 11 (2006) 502-508.

18. Tuz L.: Evaluation of Microstructure and Selected Mechanical Properties of Laser Beam Welded S690QL High-Strength Steel. Advances in Materials Science, 3/18 (2018) 34-42, https://doi.org/10.1515/adms-2017-0039.

19. Pańcikiewicz K.: Structure and Properties of Welded Joints of 7CrMoVTiB10-10 (T24) Steel. Advances in Materials Science, 1/18 (2018) 37-47, https://doi.org/10.1515/adms-2017-0026.

20. Tavakoli Shoushtari M. R., Moayed M. H. and Davoodi A.: Post-weld heat treatment influence on galvanic corrosion of GTAW of $17-4 \mathrm{PH}$ stainless steel in $3.5 \% \mathrm{NaCl}$ Corrosion Engineering Science Technology 46 (2011) 415-424.

21. Sun Y., Hebert R. J., Aindow M.: Effect of heat treatments on microstructural evolution of additively manufactured and wrought 17-4PH stainless steel, Materials and Design, 156 (2018) 429-440.

22. Mudali Kamachi U., Bhaduri A. K., Gnanamoorthy J. B.: Localised corrosion behaviour of 17-4 PH stainless steel. Materials Science and Technology 6 (1990) 475-481.

23. Jui-Hung W., Chih-Kuang L.: Effect of strain rate on high-temperature low-cycle fatigue of 17-4 PH stainless steels Materials Science and Engineering A 390 (2005) 291-298. 
24. Viswanathan U. K., Banerjee S., Krishnan R.: Effects of aging on the microstructure of 17-4 PH stainless steel. Materials Science and Engineering A 104 (1988) 181-189.

25. Chung C.-Y., Tzeng Y. C.: Effects of aging treatment on the precipitation behavior of $\varepsilon$-Cu phase and mechanical properties of metal injection molding 17-4PH stainless steel. Materials Letters 237 (2019), 228-231.

26. Matlack K. H., Bradley H. A., Thiele S., Kim J. Y., Wall J. J., Hee Joon Jung, Jianmin Qu, Laurence J. Jacobs. Nonlinear ultrasonic characterization of precipitation in 17-4PH stainless steel. NDT\&E International 71, April (2015), 8-15.

27. Yeli G., Auger M. A., Wilford K., Smith G. D.W., Bagot P. A.J., Moody M. P., Sequential nucleation of phases in a 17-4PH steel: Microstructural characterization and mechanical properties. Acta Materialia 125 (2017) 38-49.

28. McWilliams B., Pramanik B., Kudzal A., Taggart-Scarff J., High strain rate compressive deformation behavior of an additively manufactured stainless steel, Additive Manufacturing 24 (2018) 432-439.

29. Ziewiec A., Tasak E., Czech J.: Cracking of welded joints of the 17-4PH stainless martensitic steel precipitation hardened with copper, Archives of Metallurgy and Materials 50 (2012) 10551061.

30. Trzepieciński T., Pieja T., Malinowski T., Smusz R., Motyka M.: Investigation of 17-4PH steel microstructure and conditions of elevated temperature forming of turbine engine strut. Journal of Materials Processing Technology 252 (2018) 191-200.

31. Hu Z., Zhu H., Zhang H., Zeng X.: Experimental investigation on selective laser melting of 174PH stainless steel. Optics and Laser Technology, 87 (2017) 17-25

32. Lo C. H. , Shek K. H., Lai J. K. L: Recent developments in stainless steels. Materials Science and Engineering R 65 (2009) 39-104.

33. Ridley N., Stuart H., Zwell L.: Lattice parameter of $\mathrm{Fe}-\mathrm{C}$ austenites at room temperature. Transactions of the Metallurgical Society of AIME, 245 (1969) 1834-1836.

34. Ruhl R., Cohen M.: Splat quenching of iron-carbon alloys. Transactions of the Metallurgical Society of AIME 245 (1969) 241-251. 